\title{
ANALYSIS OF METAL CONTENT IN BLACK PEPPER \\ POWDER AVAILABLE IN THE SRI LANKAN MARKET
}

\author{
By \\ Prashani Thushara Sandanayake
}

Thesis submitted in partial fulfillment requirement for the award of the degree of

\section{Master of Science}

\section{In}

Food Science and Technology

Of the Faculty of Applied Sciences

University of Sri Jayawardenepura

Gangodawila, Nugegoda,

Sri Lanka. 


\section{DECLARATION}

The work in this thesis was carried out by me as a project under the supervision of Prof. Arthur Bamunuaarachchi, Dr. (Mrs.) Indira Wickramasinghe and Mr. R.M.G.B. Rajanayake and a report on this has not been submitted in whole or in part to any University or any other institution for another degree.

P. Sandanayake

Prashani T Sandanayake

$2015 \cdot 08 \cdot 12$ 
We Prof. A. Bamunuarachchi, Dr. Indira Wickramasinghe and Mr. R.M.G.B. Rajanayake joinytly here by certify that the above statement in the preceding page made by the candidate is true and this thesis is suitable for submission to the university for the purpose of evaluation.

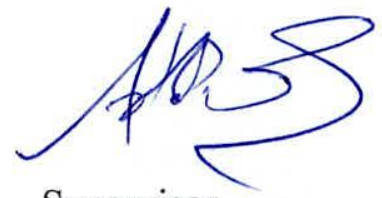

Supervisor

Prof. A. Bamunuarachchi

Emeritus Professor

Department of Food Science and Technology

Faculty of Applied Sciences,

University of Sri Jayewardenapura

Gangodawila, Nugegoda

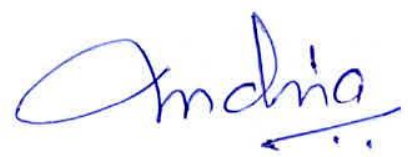

Supervisor

\section{Dr. Indira Wickramasinghe}

Senior Lecturer,

Department of Food Science and

Technology

Faculty of Applied Sciences

University of Sri Jayewardenapura,

Gangodawila, Nugegoda

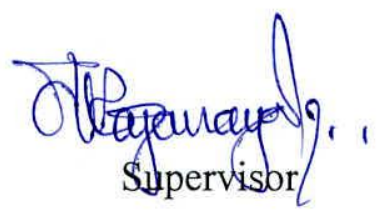

\section{Mr. R.M.G.B. Rajanayake}

City Analyst Colombo

City Analyst's Laboratory

Colombo Municipal Council

Colombo 07 


\section{TABLE OF CONTENTS}

DECLARATION

TABLE OF CONTENTS iii

LIST OF TABLES viii

LIST OF FIGURES - X

ABBREVIATIONS $\quad$ xi

ACKNOWLEDGEMENT $\quad$ xii

ABSTRACT $\quad$ xiv

CHAPTER 1- INTRODUCTION

CHAPTER 2-LITERATURE REVIEW

2.1.Taxonomy of Black pepper

2.2.History 5

2.3.Varieties 6

2.4.Major Growing Areas, soil and climate 6

$\begin{array}{ll}\text { 2.5.Crop establishment } & 7\end{array}$

2.5.2Field Planting 7

2.6Application of fertilizer $\quad 8$

$\begin{array}{lc}\text { 2.7Harvesting and post harvesting } & 8\end{array}$

2.7.1.Threshing 9 
2.7.5. Grinding

2.7.6.Packaging and storage

2.8.3. Nutritional properties

2.8.4. Antimicrobial properties

2.8.5. Antioxidant properties

2.8.6. Medicinal and Chemical Properties

2.9. Metals present in Spice/ Black Pepper

2.9.1. Effect of Trace metals in Spices

2.9.1.1. Copper in food

2.9.1.2. The role of copper

2.9.1.3. Effects of Copper deficiency

2.9.1.4. Effects of excess copper

2.9.2. Zinc in food

2.9.2.1. The role of zinc 
2.9.2.4. The effects of excess zinc 18

2.9.3.Iron in food 18

2.9.3.1.The role of iron 18

2.9.3.2.Iron toxicity 19

2.9.3.3.Effects of iron deficiency 19

2.9.3.4.Effects of excess iron 20

2.9.4.Toxic Metals 20

2.9.4.1.Lead in food 20

2.9.4.2.Effects of lead $\quad 20$

2.9..3.Cadmium in food 21

2.9.4.4.Effects of cadmium 22

2.10 Ways of metal poisoning 22

2.10.1.Sources of emission 23

2.10.2.Sources of human and plants exposure 23

2.10.3.Vehicular traffic density 23

2.10.4.Irrigation water 24

2.10.5.Compost and sludge $\quad 24$

2.10.6.Fertilizer application $\quad 24$

2.11 Analysis of metals 25

2.11.1.Atomic Absorption Spectroscopy 25

2.11.2.Flame Atomic Absorption Spectroscopy 26

2.11.3.Graphite Furnace Atomic Absorption Spectroscopy 26

$\begin{array}{ll}\text { 2.11.4.X-Ray fluorescence (XRF) Analysis } & 27\end{array}$

2.11.5.Sample Pre Treatment 28

2.11.6. Wet Digestion 28

2.11.7.Dry Ashing 28

CHAPTER 3- METERIALS AND METHODS 30 
$\begin{array}{ll}\text { 4.1 Sampling } & 40\end{array}$

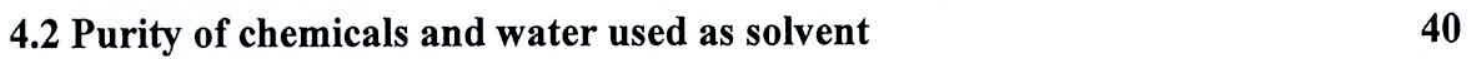

4.3 Analysis of metals in Black Pepper by Atomic absorption Spectroscopy and

X-Ray florescence spectroscopy method

4.3.1.Analysis of macro metals

4.3.2.Analysis of Micro metals using AAS and XRF method.

4.3.3.Analysis of Toxic metals

CHAPTER 5- CONCLUSION

REFERENCES 


\section{LIST OF TABLES}

Table 2.1 - Nutrient in the fertilizer mixture $\quad 8$

Table 2.2 - WHO maximum permissible limits for heavy metals in Spices 12

Table 2.3 - Specification given in Sri Lanka Standard Specification for Ground $\quad 13$

Table 3.1 - Standard series of metals for flame AAS 33

Table 3.2 - Spectrometer parameters used for AAS 34

Table 3.3 - Standard series for $\mathrm{Pb}$ and $\mathrm{Cd}$ ions $\quad 35$

Table 3.4 - Graphite Furnace parameters used in analysis of $\mathrm{Pb}$ and $\mathrm{Cd}$. 35

Table 3.5 - Operating parameters of XRF 36

Table 3.6 -Characteristic fluorescent energy values of elements 39

Table 4.I - The macro metals of black pepper brands (batch wise) $\{\mathrm{mg} / \mathrm{g}$,dry weight $1(\mathrm{DW})\}-\mathrm{ASS}$

Table 4.2 - The macro metals of black pepper brands $\{\mathrm{mg} / \mathrm{g}$ dry weight (DW) $\}$-AAS

Table 4.3 - The macro metals of Black pepper brands (brand wise) \{mg/g dry weight (DW) \}-X-Ray

Table 4.4 - The Micro metals of Black pepper brands (Batch wise) $\{\mathrm{mg} / \mathrm{g}$,dry weight (DW) $\}$-AAS

Table 4.5 - The micro metals of Black pepper brands (brand wise) $\{\mathrm{mg} / \mathrm{g}$,dry $\}$

Table 4.6 - The micro metals of Black pepper brands (Brand wise) $\{\mathrm{mg} / \mathrm{Kg}$ dry weight 
Table 4.7 - The Toxic metals of Black pepper brands (Batch wise) $\{\mu \mathrm{g} / \mathrm{g}$ dry weight (DW) $\}-$ AAS

Table 4.8 - The Toxic metals of Black pepper brands (Brand wise) $\{\mu \mathrm{g} / \mathrm{g}$ dry weight 


\section{LIST OF FIGURES}

Figure 2. 1 - Pepper Plant 5

$\begin{array}{ll}\text { Figure 2.2 - A cabinet dryer } & 10\end{array}$

Figure 2. 3 - Atomic Absorption Spectrometer 26

Figure 2. 4 - Instrumentation of graphite furnace 26

Figure 4.1. Na content of Brands, unbranded and raw from AAS method 45

Figure 4.2 - K content of Brands, unbranded and raw from AAS method 46

Figure 4.3 - K Ion content of Brands, unbranded and raw.(XRF) 46

Figure 4.4 - Mg and Calcium content of Brands, unbranded and raw from AAS method.

Figure 4.5 - Calcium Ion content of Brands, unbranded and raw. (XRF)

Figure 4.6 - Fe content of brands, unbranded and raw in Black pepper- AAS method 53

Figure 4.7 - Fe content of brands, unbranded and raw in black pepper-XRF method 54

Figure 4.8- $\mathrm{Zn}$ and $\mathrm{Cu}$ content of brands, unbranded and raw in black pepper-AAS 55

Figure 4.9 - $\mathrm{Zn}$ and $\mathrm{Cu}$ content of brands, unbranded and raw in black pepper.-XRF 56

Figure 4.10 - Mn content of brands, unbranded and raw in black pepper -AAS. $\quad 58$

Figure 4.11 - Mn content of Brands, unbranded and raw in black pepper.-XRF 59

Figure 4.12 - The Lead $(\mathrm{Pb})$ and Cadmium $(\mathrm{Cd})$ content of Black pepper -AAS 63 


\section{ABBREVIATIONS}

AAS- Atomic Absorption Spectroscopy

FAAS-Flame Atomic Absorption Spectroscopy

GFAAS-Graphite Furnace Absorption Spectroscopy

WHO- World Health Organization

XRF- X- Ray Fluorescence spectroscopy

ppm- part per million

ppb- parts per billion 


\section{ACKNOWLEDGEMENT}

My Grateful Acknowledgement with special thanks is made to my supervisors, Professor Arthur Bamunuaarachchi, Dr. Indira Wickramasinghe and Mr. R.M.G.B. Rajanayake for their tireless efforts in supervising and guiding me through the entire period for the accomplishment of this thesis.

I appreciate the assistance and guidance I received from Mr. P.Dias, Senior lecturer, University of Sri Jayewardenepura and Mr Waduge, Director, atomic Energy Authority of Sri Lanka

I would like to acknowledge with thanks the guidance I received from Mr. Asoka Sandanayake, my father- in- law for providing valuable feedback that improved my thesis.

I offer my sincere gratitude to Waruna Gunasekera my Nephew, Ms. Sajeewani Somarathna Senior Assistant Librarian, University of Colombo, My friends Melani Vithanage and Vidyani Amaradivakara for their constant support and, Guidance without which this project would not have been possible.

I take this opportunity to thank The Dr. M.A.J.Wansapala coordinator and Dr Rupika Perera co- coordinator of this M.Sc in Food Science and Technology and all other academic and nonacademic staff of Department of Food Science and Technology, University of Sri Jayawardenapura and all the staff at City Analysist Laboratory who helped me to carry out this research work.

Finally my sincere thanks to my family and friends for all the love, understanding, and encouragement support throughout the study period. 


\section{Dedication}

To my beloved husband Hareendra, Son Ashan and daughter Dinuli, for the time you had to suffer and stay without me because of my studies. I owe this one to you. 


\title{
ANALYSIS OF METAL CONTENT IN BLACK PEPPER POWDER AVAILABLE IN SRI LANKAN MARKET.
}

\section{By Prashani. T. Sandanayake.}

\begin{abstract}
Black pepper (Piper nigrum L.), is a highly valued spice crop which is originated in India and subsequently spread to other countries. As far as the export market is concerned pepper is one of the major items exported by Sri Lanka. In recent years, there has been a growing interest in monitoring heavy metal contamination of spices. Pepper has been reported to contain significant quantities of some metals which cause detrimental effects on human health.
\end{abstract}

In this study concentrations of some heavy metals (Sodium, Potassium, Calcium, Magnesium, Zinc, Copper, Iron, Manganese, Lead, and Cadmium) in five common brands and unbranded Black pepper samples which are available in the local market in Sri Lanka were determined. Whole black pepper samples were analyzed as a control to study the possible metal contaminations during the process of powdering Metal analysis was carried out by Atomic absorption spectroscopy and X-ray Fluorescence Spectroscopy. Lead and Cadmium were analyzed using Graphite Furnace whereas the other metals were analyzed by Flame Atomic Absorption spectrometry and X-ray fluorescence spectrometry. Wet digestion method was used for digestion of samples for Atomic Absorption spectrophotometry

The Study shows differences in metal concentrations of their mean values such as $\mathrm{K}>\mathrm{Ca}>\mathrm{Mg}>\mathrm{Na}>\mathrm{Fe}>\mathrm{Mn}>\mathrm{Cu}>\mathrm{Zn}>\mathrm{Cd}>\mathrm{Pb}$. The results obtained from Atomic Absorption Spectrophotometry analysis the range of metals on a dry weight basis were; 
Potassium 16604.3- 20428.7mg/kg, Calcium 1783.2683.2 mg/kg, Sodium $107.9 \mathrm{mg} / \mathrm{kg}$, Magnesium 1747.9- $2194.6 \mathrm{mg} / \mathrm{kg}$, Zinc 9.4-12.8 mg/kg, Copper 9.5-14.5 mg/kg, Ferrous $44.1-224.7 \mathrm{mg} / \mathrm{kg}$, Manganese $33.6-60.4 \mathrm{mg} / \mathrm{kg}$ lead $155.8-344.9 \mu \mathrm{g} / \mathrm{kg}$, Cadmium 212.6-363.8 $\mu \mathrm{g} / \mathrm{kg}$ respectively. The study revealed that there is compliance between the two methods. In all values only the values for Cadmium was significantly above the WHO maximum permissible limit (MPL), while the others were below the MPL inferring that the agricultural practices might be affecting cadmium contamination in pepper. The study highlighted possibility of wear and tear of machineries causing high Iron content in powdered pepper. According to the present study generally processed pepper contains more metal contents than whole pepper except for sodium, calcium and manganese ions. 